Journal of Business \& Management (COES\&RJ-JBM)

ISSN (E): 2306-7179 ISSN (P): 2306-8043

Publisher: Centre of Excellence for Scientific \& Research Journalism, COES\&RJ LLC

Online Publication Date \& Issue: 1st July 2019, Vol.7, No.3, July 2019

https://doi.org/10.25255/jbm.2019.7.3.234.251

\title{
Reviewing the Mediating Role of Quality Management Capabilities on the Effect of Information Technology on Organizational Performance
}

Laith Walid Fatafta, Department of Business Management, School of Business, The University of Jordan, Amman, Jordan, ebawayah@hotmail.com

Shaker Habis Nawafleh, AL Hussein Bin Talal University, Jordan

Heba Eid Al Darwaish, MBA/Accounting Graduate at School of Management and Finance,

The University of Jordan-Aqaba Branch, Jordan

\begin{abstract}
Abstrac:
Information Technology (IT) is considered as an important element of any organization. Its effect on global business is becoming widely felt. Also, it is extremely argued that IT is rapidly becoming the most important factor in increasing organizational performance and productivity. Also, quality management is also one of the most important management philosophies directed towards improving organization performance. The purpose of this paper is to reviewing the literature regarding the mediating role of quality management capabilities on the effect of information technology on organizational performance

Keywords:

Information technology, quality management capabilities, organizational performance

Citation:

Fatafta, Laith Walid; Nawafleh, Shaker Habis; Al Darwaish, Heba Eid (2019). Reviewing the Mediating Role of Quality Management Capabilities on the Effect of Information Technology on Organizational Performance; Journal of Business \& Management (COES\&RJ-JBM) Vol.7, No.3, pp.234-251, https://doi.org/10.25255/jbm.2019.7.3.234.251.
\end{abstract}

This work is licensed under a Creative Commons Attribution 4.0 International License. 


\section{Journal of Business \& Management (COES\&RJ-JBM), 7(3), pp. 234-251}

\section{Introduction}

Researchers stressed the crucial enabling factors of applying numerous Information Systems (IS) and specific Information Technology (IT) services (e.g. Masa'deh, et al., 2008, 2013a, 2013b; Karajeh and Maqableh, 2014; Maqableh and Karajeh, 2014; Al-Dmour et al., 2015; Almajali and Maqableh, 2015; Kateb et al., 2015; Maqableh et al., 2015; Masa'deh, 2016a, b; Tarhini et al., 2015; 2016, 2017a, 2017b; Almajali and Al-Dmour, 2016; Almajali et al., 2016; Alenezi et al., 2017; Aldmour et al., 2017a, b; Khwaldeh et al., 2017; Mikkawi and Al-Lozi, 2017; Obeidat et al., 2017; Yassien and Mufleh, 2017; Tarhini et al., 2018; Al-Dmour et al., 2019; Masa'deh, et al., 2019a, b; Obeidat et al., 2019). Also, scholars called for more research on Quality Management Capabilities (QMC) and its relationship with organizational performance, hence, the current research aims to explore the linkage among IT, quality management capabilities, and organizational performance.

This research demonstrate the definitions, characteristics and evolution of the study dimension's based on previous researches which were classify into sections; the first section represents information technology and its dimensions; electronic data interchange and enterprise resource planning. The second section represents quality management capabilities and its dimensions; customer and supplier relations and product design. Third section discusses organizational performance and its dimensions; customer satisfaction and customer responsiveness. Furthermore, the last section shows the previous studies that examined the effect of information technology on organizational performance as well as the effect of quality management capabilities on organizational performance.

\section{Literature Review}

\subsection{Information Technology (IT)}

Hajli et al. (2015) defined IT as the set of computer software, computer hardware, and communications equipment the way in which it is currently reflected in the organizational performance. IT services must satisfy and support the organization demands. Another definition of IT refers to the different ways of exchanging information by computers through IT technologies such as electronic data interchange and enterprise resource planning (Madanhire and Mbohwa, 2016). In addition, the increasing use of IT is very important to the purchasing function in terms of customer and supplier relations and reflects the demand for tools that can facilitate information exchanges, communication (Rodríguez-Escobar and González-Benito, 2015). More organizations are seeking to make maximum use of IT to increase their performance. These technologies provide fast, accurate information, and business efficiency that are relatively inexpensive (Achimugu et al., 2009). Many researchers found that IT could significantly influence an organization competitive advantage and their opinion that the technologies of IT in various areas of quality management (QM) is growing and continually expands (Wai et al., 2011).

Using IT in quality management processes may result in improving operational performance measures such as improves flexibility, faster delivery and improving costumer and supplier relationship (Sanchez-Rodriguez and Rafael Martinez-Lorente, 2011). Previous literature has devoted valuable interest to the effect between IT and quality management studying such issues a show technologies impact various aspects of quality management such as customer and supplier relations and product design (Kock, McQueen and Corner, 1997). 
Reviewing the Mediating Role of Quality Management Capabilities...

Different researchers have referred to different dimensions of information technology. According to Mulligan and Gordon (2002) discussed the information technology that has an impact on customer and supplier relationships through three dimensions (EDI, Audio response and Web-based). Johnson et al. (2007) there are two measures of information technology: electronic data interchange and Computer-aided design. Rodríguez-Escobar and GonzálezBenito (2015) discussed the information technology that impact of purchasing performance through three dimensions which are Base system, Purchasing system, and Communications System.

According to (Sanchez-Rodriguez and Rafael Martinez-Lorente, 2011; Madanhire and Mbohwa, 2016) information technology definition and for the purpose of this study information technology will be dimensioned through Electronic data interchange and Enterprise resource planning.

2.1.1. Electronic Data Interchange (EDI)

EDI is used in managing the information flow with customers and suppliers. It still in one of the most widely used technologies among organization departments and external customers (Johnson et al., 2007). EDI can be defined as a type of electronic commerce (EC) that allows organizations to exchange information and business documents electronically in a structured by machine-readable format (Kelsey, 2015). Sanchez-Rodriguez and Rafael Martinez-Lorente (2011) discussed the importance of EDI that influences on quality management capabilities (customer and supplier relations) to gain performance advantages for organizations. Therefore, EDI systems are used to share data between suppliers and customers in standardized formats through computer networks. It provides fast, accurate information, and business efficiency to the organization (Bhatt, 2001). EDI has facilitated the expansion and increase the flexibility of the inter-firm commercial trade that improves organization performance because it reduces the need for supervision while increasing the systematization (Rodríguez-Escobar and González-Benito, 2015). The use of EDI systems requires integration across the organization's legal boundaries, encompassing a network of suppliers and the company. However, the establishment of these linkages rests on the assumption of the compatible IT infrastructure between suppliers and the company (Emmelhainz, 1993). EDI systems result in reducing the coordination costs, which would induce a company to make more use of markets place that means by using electronic networks, a firm can reduce costs of communication, co-ordination and logistics by exchanging a larger volume of information in less time (Johnson et al., 2007). According to Ngai and Gunasekaran (2004), there are some factors that significantly increase success in the adoption of EDI in organization, these include technology infrastructure, workers skills in IT and top management support.

Finally, EDI is a technology used to transmit the business documents (such as orders, invoice, shipping contracts, and so on) electronically to improve the quality of customer and supplier relations, and product design to gain organization performance advantages (Takaishi et al., 2017).

2.1.2. Enterprise Resource Planning (ERP)

ERP is a management information system that optimizes the distribution of enterprise resources and helps an organization to integrate all its resources for effective application to improve its operational performance and enhance its competitiveness (De Toni et al., 2015). 


\section{Journal of Business \& Management (COES\&RJ-JBM), 7(3), pp. 234-251}

Moreover, ERP is defined a business software system that allows organizations to integrate and automate the majority of its business processes, share data and practices across the enterprise and access information in a real-time (Sammon and Adam, 2005). ERP system is ability to manage multiple areas of a firm including sales and purchases, production planning and scheduling, process design, inventory management, and quality control (Gupta and Kohli, 2006). Nonino and Panizzolo (2007) commented that ERP leads to different benefits as an increase in productivity, a higher level of efficiency in the information flow, better warehouse management, and costs reduction. Managers have also reported that the integration between ERP systems and quality management is also important for managing customers and supplier relationships and managing the product and process in the best ways (Foster and Ogden, 2008). Previous studies had argued that ERP implementation positively affects an organization performance when the enterprise information system implementation directly interacts with quality improvement systems (Laframboise and Reyes, 2005; Schniederjans and Kim, 2003; Laframboise, 2002). A recent study by Madanhire and Mbohwa (2016) defined ERP as a computer system that keeps managers informed about what is happening in real-time throughout a corporation and its global connections. Shen et al. (2016) showed that enterprise resource planning systems have been used in integrating information and accelerating its distribution across functions and departments with the aim to increase organizations' operational performance. Another research by Gloor et al. (2017) theme focuses on the details of implementing ERP and their related success and benefit. In their study pointed out that implementing an ERP system not only increased customer satisfaction and reduced operational costs but also eventually resulted in increased profits and growth of an organization.

Finally, ERP is a functional software tool that supports the areas of logistics, planning, finance, manufacturing, procurement, human resource, project management, distribution, accounting, service maintenance, and transpiration. Therefore, the primary benefit of an ERP system relates to the integration of data and processes, and improved business efficiency (Mahmud et al., 2017).

\subsection{Quality Management Capabilities (QMC)}

Quality management has been regarded as a key strategic component of competitive advantage that has been received much concern for today's organizations (Soltani et al., 2011). Most organizations are continuously enhancing their performance by improving quality of their products, and services through various quality management practices (Patyal and Maddulety, 2015). Quality management practices help to obtain quality goals and support top management in attaining quality improvement (Sousa and Voss, 2002). Quality management is a philosophy that focuses on customer satisfaction and continuous improvement that enhances the organizational performance (Malik et al., 2012). Manufacturing companies explore quality management as a strategic weapon for improving their competitive advance. Along with other factors such as information technology, quality management can extremely explain the high performance in terms of conformance quality, manufacturing cost, dependability, flexibility, time, and customer service (Phan et al., 2011). The term capability refers to resources and abilities. According to Power (2014), quality management capabilities refers to the ability of an organization to identify, utilize, and assimilate both internal and external resources/information to facilitate the completion of quality management activities in order to develop products and services that satisfy or exceed customer expectations. Cho, Jung and 
Reviewing the Mediating Role of Quality Management Capabilities...

Linderman (2017) demonstrated that behavior-oriented quality management capabilities such as support from top management, customer focus, and supplier relationship are the source of competitive advantage. In their study investigating of how quality management capabilities have a significantly positive influence on firm performance.

Different researchers have referred to different dimensions of quality management capabilities. According to Jung et al. (2009), there are three measures of quality management capabilities: employee relations, customer and supplier relations, product, and process management. Kaynak and Hartley (2008) defined five major elements that strengthen quality management capabilities: product design, customer focus, process management, training and quality data.

For the purpose of this study, quality management capabilities concept will be illustrated through its mediating role between information technology and organizational performance, which consists of two dimensions: customer and supplier relations (CSR), and product design in accordance with study conducted by Sanchez-Rodriguez and Rafael Martinez-Lorente (2011).

\subsubsection{Customer and Supplier Relations (CSR)}

Customer supplier relations in a mean of transferring information between customer and supplier, both of them should provide information about quality assurance as a feedback (Oly Ndubisi et al., 2007). It also refers to ability to manage disruptions and respond better to fluctuating demands (Rajesh and Ravi, 2015). Customer supplier relations can be defined as the extended relationship between suppliers and customers based on confidence, credibility, and mutual benefit (Kuo et al., 2016). Customer supplier relations can be understood as a set of business activities supported by both technology and processes that is directed by strategy and is designed to improve business performance (Dawson et al., 2017). It is necessary to identify the customer needs and achieve their level of satisfaction. Information technology plays a significant role in supporting relationships between the customer and the supplier using electronic data interchange to share data between both sides, this technology provides fast, accurate information, and business efficiency to the firm (Mulligan and Gordon, 2002). Danese and Romano (2011) investigated the distinct contribution of integrating internally with customers and suppliers to improve different dimensions of performance, such as cost containment and reliability.

In relation to quality, the firms should be cooperating with both the suppliers and customers to improve the quality of product and services, thus, meeting the customer needs (SanchezRodriguez and Rafael Martinez-Lorente, 2011).

\subsubsection{Product Design}

All departments within the organization have to participate in the design process and work together towards achieving the product design which meets the customer requirements (Sanchez-Rodriguez and Rafael Martinez-Lorente, 2011). Indeed, achieving a market success for some product clearly relies on identifying and satisfying the customer needs at a reasonable price. The product should be developed according to the customer perspective, demands vary from a customer to another, and thus, product features would be different (Gangurde and Akrate, 2015). Enterprise resource planning is one of the most appropriate technologies used to clarify the effect of information technology over the product design, enterprise resource planning systems were chosen because of their ability to manage multiple areas of an organization including sales and purchases, production planning and scheduling, process 


\section{Journal of Business \& Management (COES\&RJ-JBM), 7(3), pp. 234-251}

design, inventory management, quality control and human resources management (Gupta and Kohli, 2006). During the product design and development, the information technology facilitates making different functions and activities; it also makes communication between departments easier. In result, the product design which is subjected to information technology leads to a reduced development time, a reduced cost and an increased quality (Caputo and Pelagagge, 2008). According to Gruhier et al. (2017), product design has been done by considering the integration of lifecycle constraints and knowledge in product design so as to deliver best products; this means that such effort has anyway provided competitive advantages in efficiency and flexibility by improving designers' awareness and product quality.

\subsection{Organization Performance}

These days, organizations are working hard to keep up to the changes happening around them by boosting the performance base of the competition they make. Organizational performance as the ultimate dependent variable that is affected by all areas of management, and this is why the researchers consider it, because the performance gives the researchers the needed info to compare the organization to its competitors (Obeidat et al., 2016). Organizational performance can be defined as the degree to which an organization is able to meet its own needs and the needs of its stakeholders in order to survive (Middleton et al., 2003). Carton (2004) suggested that organizational performance is the voluntary association of productive assets that lead to the achievement of shared purpose. Organizational performance can also be defined as the ability to acquire and process the five resources which are the human, financial, physical, information, and technology resources in a way to achieve the organizational goals and objectives (Ramezan et al, 2013). Organizations that keep monitoring their performance are more effective and efficient in terms of uncertainty, ambiguous and risk (Obeidat et al., 2016). Tsai and Yen (2008) suggested that organizational performance can be measured by using two performance aspects, social and innovation performance in addition to Financial and market performance. Organization performance can be measured by using Mitchell's four dimensions which include relevance of the company to stakeholder needs, the efficiency of the company, effectiveness of the company and the financial viability of the company (Mitchell, 2002). Lee et al. (2008) provides another way form measuring organizational performance through stakeholder's satisfaction, organizational communication, team collaboration, strategic performance, knowledge management, and organizational growth.

Finally, Yaghoobi and Haddadi (2016) commented that measuring organizational performance involve non-financial through three dimensions which include: internal business processes customer, learning and growth. For the purpose of this study, the dimensions of non-financial performance will be used to measure organizational performance explained by its two main dimensions that include customer satisfaction and customer responsiveness, based on the study conducted by (Abdel-Maksoud et al., 2005; Digalwar et al., 2013).

\subsubsection{Customer Satisfaction}

Customer satisfaction is a main factor of an organization's success. Customer satisfaction is defined as a customer feelings of pleasure or disappointment that conclusion from comparing a product's perceived outcome with his/her expectations (Kasiri et al., 2017). Olsen et al. (2014) commented that and in order to increase customer satisfaction, organization must obtains and uses information from customers, develops a strategy to meet customer needs, and implements that strategy by being responsive to customers and collect data from customers at 
Reviewing the Mediating Role of Quality Management Capabilities...

is faction measurements and analyze them to improve organization performance. Chen (2012) reported that customer satisfaction had a positive influence on the customer purchase intentions and customer loyalty. In the study investigated the relationship between customer satisfaction and customer loyalty in the e-service context. More recent satisfaction definitions concede is an essential factor related to a company's future profit by increasing customer loyalty (Kim et al., 2015). In industrial markets, customer satisfaction as an important part of business strategy and a key driver of profitability and market value (Jean et al., 2016). According to Pizam et al. (2016), customer satisfaction is the leading criterion for determining the quality that is actually delivered to customers through the product/service and by the after sales service.

Finally, various studies have found that higher level of customer satisfaction ultimately leads to a customer loyalty and word of mouth recommendations (Kasiri et al., 2017; Lai et al., 2006).

\subsubsection{Customer Responsiveness}

Customer Responsiveness may be one of the most important capabilities needed for organization to achieve competitive advantage (Santos Bernardes and Hanna, 2009). Reichhart and Holweg (2007) regard responsiveness as equal to the delivery lead-time for a certain product. Many companies emphasize the customer responsiveness and quality as a means to stay in business over their lifetime (Kasiri et al., 2017). Noordin et al. (2012) stated that customer responsiveness as the extent of capability of a firm in providing speedy services, variety of services, and desire to help customers within the service delivery system. Customer responsiveness can be defined by the actions taken in response to market with emphasizing individual's needs of target customer. For the industrial firm, customer responsiveness can be met by added-value activities as building relationship with customers and solving customers' problems (Pehrsson, 2014). In other words, customer responsiveness is the ability to react within an appropriate time-scale to customer demand or changes in the marketplace, to bring about or maintain competitive advantage (Mandal, 2015). According to Iberahim et al. (2016), responsiveness is defined as the ability to respond to customer requirements timely and flexibly. Additionally, customer responsiveness refers to the probability of fulfilling a customer order within a quoted lead-time. Compared with other measures of responsiveness such as expected lead-time this definition reflects the likelihood of a customer receiving his order at a preferred due date (Hum et al., 2018). Finally, responsiveness in the eyes of end customers, combining short lead times with high conformance quality to offer high adaptability to demand fluctuations. Therefore, profitability increases because of reduced distribution inventories, fewer quality and maintenance issues, higher sales growth, and better customer retention (Schonberger and Brown, 2017).

\section{Information Technology and Organizational Performance}

Ongoing studies of organizational performance and information technology aim to identify the effect of information technology on the organizational performance. They suggested that information technology and the complementary resources of the firm affect the effectiveness of business processes with consequently improved organizational performance; they also concluded that investment on IT leads to a lower average total cost per unit of output (Cetinkaya et al., 2014; Liang et al., 2010). Benitez-Amado et al. (2010) stated that IT resources such as technological IT resources can enable a firm to improve its ability to develop a working 


\section{Journal of Business \& Management (COES\&RJ-JBM), 7(3), pp. 234-251}

environment that encourages creativity and rapid development. Among the many studies that have investigated the relationship between information technology and organizational performance, Pérez-López and Alegre (2012) argued that information technology is related to firm performance. Additionally, they proposed that IT competency, on its own, is insufficient to generate and maintain a competitive advantage. Firms need complementary strategic capabilities such as knowledge management to strengthen the effect of IT competency on firm performance. Mandal and Bagchi (2016) demonstrated that information technology with no doubt is exerting ever increasing influences on corporate growth and profitability. Sustainability can also be enhanced through technology, information and knowledge; all of which can create competitive advantage and add value in markets. Another study by Lindh and Nordman (2017) showed that information technology ability to contribute to performance in industrial markets. His study also revealed that the information technology acts as an agent for increasing strength and performance in business in industrial markets.

\section{Information Technology and Quality Management Capabilities}

Information technology is strongly related to all quality management capabilities. Therefore, the use of Information technology to facilitate quality management and initiatives is definitely growing and is being an essential ingredient to quality success. This is mainly supported in the literature by the work of various researchers. The work of Dewhurst et al. (2003) and Mjema et al. (2005) can be used to demonstrate this ever-increasing need to use Information technology to support quality management and the resulting increase in impact of Information technology on quality management. Dewhurst et al. (2003) examine the various beneficial impacts that information technology may have on quality management capabilities. Their findings indicated that quality management capabilities needed information technology in order to improving costumer and supplier relationship, improving design process and improving the decision process in quality departments. Another study by Wai et al. (2011) indicated that the firms should in no way switch their focus from quality to information technology, but instead focus on how information technology can be used to enhance quality management capabilities. In their study revealed that manufacturing organizations were making more use of information technology to support quality management capabilities within their current information technology capabilities. Hassab Elnaby et al. (2012) reported that firms seek to improve or maintain their competitiveness by using information systems (electronic data interchange and enterprise resource planning) to improve quality management capabilities (customer and supplier relations, product design and customer service) in order to get shorten cycle times and reduce cost. In their study these information systems enable firms to achieve competitive advantage and superior long-term performance. Khanam et al. (2016) found the role of information technology for quality management to enhance the organizational performance.

\section{Conclusion}

Quality management is a collection of management principles, practices and techniques to improve organizational performance. Therefore, quality management approach helps in improving business performance and satisfying demands of internal external customers (Lenka et al., 2010). Sanchez-Rodriguez and Rafael Martinez-Lorente (2011) examined the effect of quality management capabilities on organizational performance. Their findings also confirmed the interaction between quality management capabilities and organizational performance by showing that quality management capabilities are likely to influence both quality performance 
and organizational performance. Sabella et al. (2014) measured the relationship between organizational performance and quality of management. Their findings indicated that companies needed quality management in order to improve the organizational performance to enhance their responsiveness. Therefore, quality management is substantially good for any organization as long as they are implemented the right way. A recent study by Jiménez-Jiménez et al. (2015) studied the relationship between organizational performance and quality management. Their study also revealed that quality management can be defined as an integrated effort to achieve and maintain high-quality products based on the maintenance of continuous process improvement and error prevention, at all levels and in all functions of the organization, with the aim of reaching and even exceeding customer's expectations. Another study by Al-Dhaafri et al. (2016) stated that organizational performance can be positively affected by quality management. In their study investigated the relationship between quality management and organizational performance in Dubai organizations.

\section{References}

Abdel-Maksoud, A., Dugdale, D., and Luther, R. (2005). Non-Financial Performance Measurement in Manufacturing Companies. The British Accounting Review, 37(3), 261-297.

Achimugu, P., Oluwagbemi, O., Oluwaranti, A., and Afolabi, B. (2009). Adoption of Information and Communication Technologies in Developing Countries: An Impact Analysis. Journal of Information Technology Impact, 9(1), 37-46.

Al-Dhaafri, H.S., Al-Swidi, A.K., and Yusoff, R.Z.B. (2016). The Mediating Role of Total Quality Management between the Entrepreneurial Orientation and the Organizational Performance. The TQM Journal, 28(1), 89-111.

Al-Dmour, R., Al Haj Dawood, E., Al-Dmour, H., and Masa'deh, R. (2019). The Effect of Customer Lifestyle Patterns on the Use of Mobile Banking Applications in Jordan. Int. J. Electronic Marketing and Retailing, Forthcoming.

Aldmour, R., Hammdan, F., Dmour, H., Alrowwad, A., and Khwaldeh, S. (2017a). The Effect of Lifestyle on Online Purchasing Decision for Electronic Services: The Jordanian Flying E-Tickets Case. Asian Social Science, 13(11), 157-169.

Aldmour, R., Masa'deh, R., and Obeidat, B. (2017b). Factors Influencing the Adoption and Implementation of HRIS Applications: Are they Similar. International Journal of Business Innovation and Research, 14(2), 139-167.

Al-Dmour, R, Obeidat, B., and Almajali, D. (2015). The Practice of HRIS Applications in Business Organizations in Jordan: An Empirical Study. 4th Scientific \& Research Conference on New Trends in Business, Management and Social Sciences (COES\&RJ-TK15/1). 
Alenezi, H., Tarhini, A., Alalwan, A., and Al-Qirim, N. (2017). Factors Affecting the Adoption of EGovernment in Kuwait: A Qualitative Study. Electronic Journal of e-Government, 15(2), 84-102.

Almajali, D., and Al-Dmour, R. (2016). The Role of Information Technology in Motivating Students to Accept E-Learning Adoption in Universities: A Case Study in Jordanian Universities. Journal of Business \& Management (COES\&RJ-JBM), 4(1), 36-46.

Almajali, D., and Maqableh, M. (2015). Assessing the Digital Divide Status of the Jordanian Telecentre. International Journal of Communications, Network and System Sciences, 8(11), 428439.

Almajali, D., Masa'deh, R., and Al-Lozi, M. (2016). Determinants of the Actual Use of E-Learning Systems: An Empirical Study on Zarqa University in Jordan. Journal of Social Sciences (COES\&RJJSS), 5(2), 172-200.

Altamony, H., and Gharaibeh, A. (2017). The Role of Academic Researcher to Mintzberg's Managerial Roles. International Journal of Business Management and Economic Research, 8(2), 920-925.

Benitez-Amado, J., Llorens-Montes, F.J., and Nieves Perez-Arostegui, M. (2010). Information Technology-Enabled Intrapreneurship Culture and Firm Performance. Industrial Management \& Data Systems, 110(4), 550-566.

Bhatt, G.D. (2001). Business Process Improvement through Electronic Data Interchange (EDI) Systems: An Empirical Study. Supply Chain Management: An International Journal, 6(2), 60-74.

Caputo, A.C., and Pelagagge, P.M. (2008). Effects of Product Design on Assembly Lines Performances: A Concurrent Engineering Approach. Industrial Management \&Data Systems, 108(6), 726-749.

Carton, R.B. (2004). Measuring Organizational Performance: An Exploratory Study (Doctoral Dissertation, University of Georgia).

Cetinkaya, A., Ergul, M., and Uysal, M. (2014). Quality of Relationship on Information Technology Outsourcing for Organizational Success in Hospitality Industry. Journal of Hospitality and Tourism Technology, 5(3), 229-244.

Chen, S.C. (2012). The Customer Satisfaction-Loyalty Relation in an Interactive E-Service Setting: The Mediators. Journal of Retailing and Consumer Services, 19(2), 202-210.

Cho, Y.S., Jung, J.Y., and Linderman, K. (2017). The QM Evolution: Behavioral Quality Management as a Firm's Strategic Resource. International Journal of Production Economics, 191, 233-249. 
Danese, P., and Romano, P. (2011). Supply Chain Integration and Efficiency Performance: A Study on the Interactions between Customer and Supplier Integration. Supply Chain Management: An International Journal, 16(4), 220-230.

Dawson, B., Young, L., Murray, J.M., and Wilkinson, I. (2017). Drivers of Supplier-Customer Relationship Profitability in China: Assessing International Joint Ventures versus State Owned Enterprises. Industrial Marketing Management, 66, 29-41.

De Toni, A.F., Fornasier, A., and Nonino, F. (2015). The Impact of Implementation Process on the Perception of Enterprise Resource Planning Success. Business Process Management Journal, 21(2), 332-352.

Dewhurst, F., Martínez Lorente, A.R., and Dale, B.G. (2003). Total Quality Management and Information Technologies: An Exploration of the Issues. International Journal of Quality \& Reliability Management, 16(4), 392-406.

Digalwar, A., Tagalpallewar, A., and K. Sunnapwar, V. (2013). Green Manufacturing Performance Measures: An Empirical Investigation from Indian Manufacturing Industries. Measuring Business Excellence, 17(4), 59-75.

Emmelhainz, M.A. (1993). Strategic Issues of EDI Implementation. Journal of Business Logistics, 9(2), 55.

Foster Jr, S.T., and Ogden, J. (2008). On Differences in How Operations and Supply Chain Managers Approach Quality Management. International Journal of Production Research, 46(24), 6945-6961.

Gangurde, S.R., and Akarte, M.M. (2015). Segmentation based Product Design Using Preferred Features. Benchmarking: An International Journal, 22(6), 1096-1114.

Gloor, P., Colladon, A.F., Giacomelli, G., Saran, T., and Grippa, F. (2017). The Impact of Virtual Mirroring on Customer Satisfaction. Journal of Business Research, 75, 67-76.

Gruhier, E., Demoly, F., and Gomes, S. (2017). A Spatiotemporal Information Management Framework for Product Design and Assembly Process Planning Reconciliation. Computers in Industry, 90, 17-41.

Gupta, M., and Kohli, A. (2006). Enterprise Resource Planning Systems and its Implications for Operations Function. Technovation, 26(5), 687-696.

Hajli, M., Sims, J.M., and Ibragimov,V. (2015). Information Technology (IT) Productivity Paradox in the $21^{\text {st }}$ Century. International Journal of Productivity and Performance Management, 64(4), 457478. 
Hassab Elnaby, H.R., Hwang, W., and Vonderembse, M.A. (2012). The Impact of ERP Implementation on Organizational Capabilities and Firm Performance. Benchmarking: An International Journal, 19(4/5), 618-633.

Hum, S.H., Parlar, M., and Zhou, Y. (2018). Measurement and Optimization of Responsiveness in Supply Chain Networks with Queueing Structures. European Journal of Operational Research, 264(1), 106-118.

Iberahim, H., Taufik, N.M., Adzmir, A.M., and Saharuddin, H. (2016). Customer Satisfaction on Reliability and Responsiveness of Self Service Technology for Retail Banking Services. Procedia Economics and Finance, 37, 13-20.

Jean, R.J., Wang, Z., Zhao, X., and Business, R.R. (2016). Drivers and Customer Satisfaction Outcomes of CSR in Supply Chains in Different Institutional Contexts. International Marketing Review, 33(4), 514-529.

Jiménez-Jiménez, D., Martinez-Costa, M., Martínez-Lorente, A.R., and Rabeh, H.A. (2015). Total Quality Management Performance in Multinational Companies: A Learning Perspective. The TQM Journal, 27(3), 328-340.

Johnson, P.F., Klassen, R.D., Leenders, M.R., and Awaysheh, A. (2007). Utilizing E-Business Technologies in Supply Chains: The Impact of Firm Characteristics and Teams. Journal of Operations Management, 25(6), 1255-1274.

Jung, J.Y., Jian Wang, Y., and Wu, S. (2009). Competitive Strategy, TQM Practice, and Continuous Improvement of International Project Management: A Contingency Study. International Journal of Quality \& Reliability Management, 26(2), 164-183.

Karajeh, H., and Maqableh, M. (2014). Security of Cloud Computing Environment. The 23rd IBIMA Conference on Vision 2020: Sustainable Growth, Economic Development, and Global Competitiveness, USA, 2202-2215.

Kateb, M., Swies, R., Obeidat, B., and Maqableh, M. (2015). An Investigation on the Critical Factors of Information System Implementation in Jordanian Information Technology Companies. European Journal of Business and Management, 7(36), 11-28.

Khwaldeh, S., Al-Hadid, I., Masa'deh, R., and Alrowwad, A. (2017). The Association between EServices Web Portals Information Quality and ICT Competence in the Jordanian Universities. Asian Social Science, 13(3), 156-169.

Kasiri, L.A., Cheng, K.T.G., Sambasivan, M., and Sidin, S.M. (2017). Integration of Standardization and Customization: Impact on Service Quality, Customer Satisfaction, and Loyalty. Journal of Retailing and Consumer Services, 35, 91-97. 
Kaynak, H., and Hartley, J.L. (2008). A Replication and Extension of Quality Management into the Supply Chain. Journal of Operations Management, 26(4), 468-489.

Kelsey, P. (2015). Implementing EDIX12 Book Acquisitions at a Medium-Sized University Library. New Library World, 116(7/8), 383-396.

Khanam, S., Siddiqui, J., and Talib, F. (2016). Role of Information Technology in Total Quality Management: A Literature Review. International Journal of Advanced Research in Computer Engineering \&Technology, 2(8), 2433-2445.

Kim, M., Vogt, C.A., and Knutson, B.J. (2015). Relationships among Customer Satisfaction, Delight, and Loyalty in the Hospitality Industry. Journal of Hospitality \& Tourism Research, 39(2), 170-197.

Kock, N.F., McQueen, R.J., and Corner, J.L. (1997). The Nature of Data, Information and Knowledge Exchanges in Business Processes: Implications for Process Improvement and Organizational Learning. The Learning Organization, 4(2), 70-80.

Kuo, Y., Yang, T., Parker, D., and Sung, C.H. (2016). Integration of Customer and Supplier Flexibility in a Make-to-Order Industry. Industrial Management \& Data Systems, 116(2), 213-235.

Laframboise, K. (2002). Business Performance and Enterprise Resource Planning. ECIS 2002 Proceedings, 101.

Laframboise, K., and Reyes, F. (2005). Gaining Competitive Advantage from Integrating Enterprise Resource Planning and Total Quality Management. Journal of Supply Chain Management, 41(3), 49-64.

Lai, F., Zhao, X., and Wang, Q. (2006). The Impact of Information Technology on the Competitive Advantage of Logistics Firms in China. Industrial Management \& Data Systems, 106(9), 1249-1271.

Lee, A.H., Chen, W.C., and Chang, C.J. (2008). A Fuzzy AHP and BSC Approach for Evaluating Performance of IT Department in the Manufacturing Industry in Taiwan. Expert Systems with Applications, 34(1), 96-107.

Lenka, U., Suar, D., and Mohapatra, P.K. (2010). Soft and Hard Aspects of Quality Management Practices Influencing Service Quality and Customer Satisfaction in Manufacturing-Oriented Services. Global Business Review, 11(1), 79-101.

Liang, T.P., You, J.J., and Liu, C.C. (2010). A Resource-based Perspective on Information Technology and Firm Performance: A Meta-Analysis. Industrial Management \& Data Systems, 110(8), 1138-1158. 


\section{Journal of Business \& Management (COES\&RJ-JBM), 7(3), pp. 234-251}

Lindh, C., and Nordman, E. (2017). Information Technology and Performance in Industrial Business Relationships: The Mediating Effect of Business Development. Journal of Business \& Industrial Marketing, 32(7), 998-1008.

Madanhire, I., and Mbohwa, C. (2016). Enterprise Resource Planning (ERP) in Improving Operational Efficiency: Case Study. Procedia CIRP, 40, 225-229.

Mahmud, I., Ramayah, T., and Kurnia, S. (2017). To Use or not to Use: Modeling End User Grumbling as User Resistance in Pre-Implementation Stage of Enterprise Resource Planning System. Information Systems, 69, 164-179.

Malik, A., Sinha, A., and Blumenfeld, S. (2012). Role of Quality Management Capabilities in Developing Market-based Organisational Learning Capabilities: Case Study Evidence from Four Indian Business Process Outsourcing Firms. Industrial Marketing Management, 41(4), 639-648.

Mandal, P., and Bagchi, K. (2016). Strategic Role of Information, Knowledge and Technology in Manufacturing Industry Performance. Industrial Management \& Data Systems, 116(6), 1259-1278.

Mandal, S. (2015). An Empirical-Relational Investigation on Supply Chain Responsiveness. International Journal of Logistics Systems and Management, 20(1), 59-82.

Maqableh, M., and Karajeh, H. (2014). Job Scheduling for Cloud Computing using Neural Networks. Communications and Network, 6(3), 191-200.

Maqableh, M., Rajab, L., Quteshat, W., Khatib, T., and Karajeh, H. (2015). The Impact of Social Media Networks Websites Usage on Students' Academic Performance. Communications and Network, 7(4), 159-171.

Masa'deh, R. (2016a). The Role of Knowledge Management Infrastructure in Enhancing Job Satisfaction at Aqaba Five Star Hotels in Jordan. Communications and Network, 8(4), 219-240.

Masa'deh, R. (2016b). The Role of Emotional Intelligence in Enhancing Organizational Effectiveness: The Case of Information Technology Managers in Jordan. International Journal of Communications, Network and System Sciences, 9(6), 234-249.

Masa'deh, R., Almajali, D., Alrowwad, A., and Obeidat, B. (2019a). The Role of Knowledge Management Infrastructure in Enhancing Job Satisfaction: A Developing Country Perspective. Interdisciplinary Journal of Information, Knowledge, and Management, 14, 1-25.

Masa'deh, R., Gharaibeh, A., Maqableh, M., and Karajeh, H. (2013a). An Empirical Study of Antecedents and Outcomes of Knowledge Sharing Capability in Jordanian Telecommunication Firms: A Structural Equation Modeling Approach. Life Science Journal, 10(4), 2284-2296. 
Masa'deh, R., Hunaiti, Z., and Bani Yaseen, A. (2008). An Integrative Model Linking IT-Business Strategic Alignment and Firm Performance: The Mediating Role of Pursuing Innovation and Knowledge Management Strategies. Communications of the International Business Information Management Association (IBIMA) Journal.

Masa'deh, R., Obeidat, B., Maqableh, M., and Shah, M. (2019b). The Impact of Business Intelligence Systems on an Organization's Effectiveness: The Role of Metadata Quality from a Developing Country's View. International Journal of Hospitality \& Tourism Administration, Forthcoming.

Masa'deh, R., Shannak, R., and Maqableh, M. (2013b). A Structural Equation Modeling Approach for Determining Antecedents and Outcomes of Students' Attitude toward Mobile Commerce Adoption. Life Science Journal, 10(4), 2321-2333.

Middleton, K., Peh, W., Southern, S., Griffin, H., Sotlar, K., Nakahara, T., ...and Jenkins, D. (2003). Organization of Human Papillomavirus Productive Cycle during Neoplastic Progression provides a Basis for Selection of Diagnostic Markers. Journal of Virology, 77(19), 10186-10201.

Mikkawi, B., and Al-Lozi, M. (2017). The Impact of Knowledge Management Infrastructure on Academic Staff Effectiveness: An Empirical Study at The University of Jordan. Jordan Journal of Business Administration, 13(1), 95-127.

Mitchell, H. (2002). Strategic Worth of Human Resources: Driving Organizational Performance. Universalia, Canada.

Mjema, E.A.M., Victor, M.A.M., and Mwinuka, M.S.M. (2005). Analysis of Roles of IT on Quality Management. The TQM Magazine, 17(4), 364-374.

Mulligan, P., and Gordon, S.R. (2002). The Impact of Information Technology on Customer and Supplier Relationships in the Financial Services. International Journal of Service Industry Management, 13(1), 29-46.

Ngai, E.W., and Gunasekaran, A. (2004). Implementation of EDI in Hong Kong: An Empirical Analysis. Industrial Management and Data Systems, 104(1), 88-100.

Nonino, F., and Panizzolo, R. (2007). Integrated Production/Distribution Planning in the Supply Chain: The Febal Case Study. Supply Chain Management: An International Journal, 12(2), 150-163.

Noordin, A., Hasnan, N., and Osman, H. (2012). Service Innovation of Postal and Courier Services in Malaysia: Will it Lead to Customer Responsiveness. International Proceedings of Economics Development \& Research, 42, 205-209. 


\section{Journal of Business \& Management (COES\&RJ-JBM), 7(3), pp. 234-251}

Obeidat, B., Tarhini, A., and Aqqad, N. (2016). The Impact of Transformational Leadership on Organizational Performance via the Mediating Role of Corporate Social Responsibility: A Structural Equation Modeling Approach. International Business Research, 10(1), 199.

Obeidat, B., Tarhini, A., and Aqqad, N. (2017). The Impact of Intellectual Capital on Innovation via the Mediating Role of Knowledge Management: A Structural Equation Modeling Approach. International Journal of Knowledge Management Studies, 8(3/4), 273-298.

Obeidat, O., Tarhini, A., and Aqqad, N. (2019). The Relationship among Emotional Intelligence, Conflict Management Styles, and Job Performance in Jordanian Banks. International Journal of Human Resources Development and Management, Forthcoming.

Olsen, L., Witell, L., and Gustafsson, A. (2014). Turning Customer Satisfaction Measurements into Action. Journal of Service Management, 25(4), 556-571.

Oly Ndubisi, N., Kok Wah, C., and Ndubisi, G.C. (2007). Supplier-Customer Relationship Management and Customer Loyalty: The Banking Industry Perspective. Journal of Enterprise Information Management, 20(2), 222-236.

Patyal, V.S., and Maddulety, K. (2015). Interrelationship between Total Quality Management and Six Sigma: A Review. Global Business Review, 16(6), 1025-1060.

Pehrsson, A. (2014). Firms' Customer Responsiveness and Performance: The Moderating Roles of Dyadic Competition and Firm's Age. Journal of Business \& Industrial Marketing, 29(1), 34-44.

Pérez-López, S., and Alegre, J. (2012). Information Technology Competency, Knowledge Processes and Firm Performance. Industrial Management \& Data Systems, 112(4), 644-662.

Phan, A.C., Abdallah, A.B., and Matsui, Y. (2011). Quality Management Practices and Competitive Performance: Empirical Evidence from Japanese Manufacturing Companies. International Journal of Production Economics, 133(2), 518-529.

Pizam, A., Shapoval, V., and Ellis, T. (2016). Customer Satisfaction and its Measurement in Hospitality Enterprises: A Revisit and Update. International Journal of Contemporary Hospitality Management, 28(1), 2-35.

Power, D. (2014). Competence and Capability in Quality in the High-tech Sector: An International Comparison. International Journal of Operations \& Production Management, 34(9), 1184-1209.

Rajesh, R., and Ravi, V. (2015). Supplier Selection in Resilient Supply Chains: A Grey Relational Analysis Approach. Journal of Cleaner Production, 86, 343-359. 
Ramezan, M., Sanjaghi, M.E., and Rahimian Kalatehbaly, H. (2013). Organizational Change Capacity and Organizational Performance: An Empirical Analysis on an Innovative Industry. Journal of Knowledge-based Innovation in China, 5(3), 188-212.

Reichhart, A., and Holweg, M. (2007). Creating the Customer-Responsive Supply Chain: A Reconciliation of Concepts. International Journal of Operations \& Production Management, 27(11), 1144-1172.

Rodríguez-Escobar, J.A., and González-Benito, J. (2015). The Role of Information Technology in Purchasing Function. Journal of Business \& Industrial Marketing, 30(5), 498-510.

Sabella, A., Kashou, R., and Omran, O. (2014). Quality Management Practices and their Relationship to Organizational Performance. International Journal of Operations \& Production Management, 34(12), 1487-1505.

Sammon, D., and Adam, F. (2005). Towards a Model of Organisational Prerequisites for Enterprisewide Systems Integration: Examining ERP and Data Warehousing. Journal of Enterprise Information Management, 18(4), 458-470.

Sanchez-Rodriguez, C., and Rafael Martinez-Lorente, A. (2011). Effect of IT and Quality Management on Performance. Industrial Management \& Data Systems, 111(6), 830-848.

Santos Bernardes, E., and Hanna, M.D. (2009). A Theoretical Review of Flexibility, Agility and Responsiveness in the Operations Management Literature: Toward a Conceptual Definition of Customer Responsiveness. International Journal of Operations \& Production Management, 29(1), 30-53.

Schniederjans, M.J., and Kim, G.C. (2003). Implementing Enterprise Resource Planning Systems with Total Quality Control and Business Process Reengineering: Survey Results. International Journal of Operations \& Production Management, 23(4), 418-429.

Schonberger, R.J., and Brown, K.A. (2017). Missing Link in Competitive Manufacturing Research and Practice: Customer-responsive Concurrent Production. Journal of Operations Management, 49, 83-87.

Shen, Y.C., Chen, P.S., and Wang, C.H. (2016). A Study of Enterprise Resource Planning (ERP) System Performance Measurement using the Quantitative Balanced Scorecard Approach. Computers in Industry, 75, 127-139.

Soltani, E., Azadegan, A., Liao, Y.Y., and Phillips, P. (2011). Quality Performance in a Global Supply Chain: Finding out the Weak Link. International Journal of Production Research, 49(1), 269-293. 
Sousa, R., and Voss, C.A. (2002). Quality Management Re-visited: A Reflective Review and Agenda for Future Research. Journal of Operations Management, 20(1), 91-109.

Takaishi, R., Usmanov, D.T., Ninomiya, S., Sakai, Y., Hiraoka, K., Wada, H., ...and Yamabe, S. (2017). Analysis of Fluorene and 9, 9-dialkylfluorenes by Electrospray Droplet Impact (EDI)/SIMS. International Journal of Mass Spectrometry, 419, 29-36.

Tarhini, A., Alalwan, A., Al-Qirim, N., and Algharabat, R. (2018). An Analysis of the Factors Influencing the Adoption of Online Shopping. International Journal of Technology Diffusion (IJTD), 9(3), 68-87.

Tarhini, A., Al-Badi, A., Almajali, M., and Alrabayaah, S. (2017a). Factors Influencing Employees' Intention to Use Cloud Computing. Journal of Management and Strategy, 8(2), 47.

Tarhini, A., Al-Busaidi, K., Bany Mohammed, A., and Maqableh, M. (2017b). Factors Influencing Students' Adoption of E-Learning: A Structural Equation Modeling Approach. Journal of International Education in Business, 10(2), 164-182.

Tarhini, A., Bany Mohammed, A., and Maqableh, M. (2016). Modeling Factors Affecting Student's Usage Behaviour of E-Learning Systems in Lebanon. International Journal of Business and Management, 11(2), 299.

Tarhini, A., Mgbemena, C., and Trab, MSA. (2015). User Adoption of Online Banking in Nigeria: A Qualitative Study. Journal of Internet Banking and Commerce, 20(3), 1-8.

Tsai, C.F., and Yen, Y.F. (2008). A Model to Explore the Mystery between Organizations' Downsizing Strategies and Firm Performance: Integrating the Perspectives of Organizational Change, Strategy and Strategic Human Resource Management. Journal of Organizational Change Management, 21(3), 367-384.

Wai, L., Seebaluck, A., and Teeroovengadum, V. (2011). Impact of Information Technology on Quality Management Dimensions and its Implications. European Business Review, 23(6), 592-608.

Yaghoobi, T., and Haddadi, F. (2016). Organizational Performance Measurement by a Framework Integrating BSC and AHP. International Journal of Productivity and Performance Management, 65(7), 959-976.

Yassien, E., and Mufleh, M. (2017). The Impact of ERP System's Usability on Enterprise Resource Planning Project Implementation Success via the Mediating Role of User Satisfaction. Journal of Management Research, 9(3), 49-71. 